\title{
Effect of late HIV diagnosis on HIV-related mortality among adults in general hospitals of Central Zone Tigray, northern Ethiopia: a retrospective cohort study
}

This article was published in the following Dove Press journal: HIVIAIDS - Research and Palliative Care

22 September 2017

Number of times this article has been viewed

\author{
Hadera Belay' \\ Fessahaye Alemseged ${ }^{2}$ \\ Teklit Angesom' \\ Solomon Hintsa' \\ Mebrahtu Abay' \\ 'Department of Public Health, College \\ of Health Sciences, Aksum University, \\ Aksum, Ethiopia; ${ }^{2}$ Department of \\ Epidemiology, College of Medicine \\ and Health Sciences, Jimma University, \\ Jimma, Ethiopia
}

Background: The global incidence of HIV infection is not significantly decreasing, especially in sub-Saharan African countries, including Ethiopia. Though there is availability and accessibility of free HIV services, people are not being diagnosed early for HIV, and hence patients are still dying of HIV-related causes. This research is aimed at verifying the effect of late diagnosis of HIV on HIV-related mortality in Central Zone Tigray, Ethiopia.

Methods: A retrospective cohort study among adult ( $\geq 15$ years old) HIV patients in three general hospitals of Tigray was conducted. Record reviews were carried out retrospectively from 2010 to 2015. Sample size was determined using stpower Cox in Stata software. Data were entered into EpiData version 3.1 software and transferred to Stata version 12 for analysis. Both bivariable and multivariable analyses were performed using Cox regression model to compare the HIV-related mortality of exposed (cluster of differentiation 4 cells count $<350$ cells $/ \mathrm{mm}^{3}$ ) and nonexposed ( $\geq 350$ cells $/ \mathrm{mm}^{3}$ ) patients using adjusted hazard ratio (AHR) at 95\% confidence interval $(\mathrm{CI})$.

Result: In all, 638 HIV patients were analyzed, contributing 2,105.6 person-years. Forty-eight (7.5\%) patients died of HIV-related causes with a mortality rate of 2.28 per 100 person-years. In the multivariable Cox regression model, patients with late diagnosis of HIV had a higher risk of mortality ( $\mathrm{AHR}=3.22,95 \% \mathrm{CI}: 1.17-8.82$ ) than patients with early diagnosis of HIV. Rural residence $(\mathrm{AHR}=1.96,95 \% \mathrm{CI}: 1.05-3.68)$, unemployment $(\mathrm{AHR}=2.70,95 \% \mathrm{CI}: 1.03-7.08)$, bedridden patients (AHR $=2.98,95 \% \mathrm{CI}: 1.45-6.13$ ), ambulatory patients (AHR $=2.54,95 \%$ CI: $1.05-6.15)$, and baseline hemoglobin level of $<11 \mathrm{mg} / \mathrm{dL}$ (AHR $=3.06,95 \% \mathrm{CI}: 1.51-6.23)$ were other independent predictors of mortality.

Conclusion and recommendations: Late diagnosis of HIV increased HIV-related mortality. Rural residence, unemployment, bedridden and ambulatory patients, and baseline hemoglobin level $<11 \mathrm{mg} / \mathrm{dL}$ were also independent predictors of HIV-related mortality.

Keywords: HIV, early/late diagnosis, CD4 cell count, HIV-related mortality, Tigray, Ethiopia

\section{Background}

Worldwide, there are about 36.7 million people living with HIV, 2.1 million newly infected people with HIV, and 1.1 million deaths from HIV until the end of 2015. ${ }^{1-4}$ Sub-Saharan Africa is the most affected region, with 25.6 (23.1-28.5) million people living with HIV. ${ }^{1}$ According to the World Health Organization (WHO) 2016 report, approximately 18.2 million people are under antiretroviral therapy (ART) follow-up globally. ${ }^{4}$ Based on the national HIV AIDS Prevention and Control Office 2016 report of Ethiopia, 740,000 persons are living in Ethiopia with HIV, 84,000 (12\%) are chil-
Correspondence: Mebrahtu Abay Department of Public Health, College of Health Sciences, PO Box 298, Aksum University, Aksum, Ethiopia

Tel +25I 920256199

Email gmebrahtuabay@gmail.com 
dren, with an overall prevalence rate of $1.2 \%$, of which only $377,000(50.9 \%)$ are under ART. ${ }^{5}$

With free HIV testing and ART service there should be no HIV-related death; however, death of HIV patients in the world, especially in developing countries such as Ethiopia, is still being reported. ${ }^{2,4,6-11}$ One of the contributors for these deaths could be late diagnosis of HIV. ${ }^{12-16}$ As early diagnosis is key for tracing HIV-positive people, this leads to initiation of ART earlier, and hence might significantly reduce the rate of HIV-related mortality., ${ }^{4,13,17-19}$ Currently, Ethiopia has changed the eligibility criteria of HIV-positive people for ART utilization. The country is implementing a guideline that every HIV-positive individual should get ART treatment whether he/she is diagnosed late $(<350$ cells $/ \mathrm{mm}^{3}$ cluster of differentiation 4 [CD4] cell count) or early in the disease process ( $\geq 350$ cells $/ \mathrm{mm}^{3} \mathrm{CD} 4$ cell count). ${ }^{1,710,20}$ Drug and testing availability in Ethiopia are expanding to primary health care facilities and through campaign services. However, there are hardly any studies that confirm if improved availability and accessibility of HIV services has positively affected people to be diagnosed earlier. ${ }^{4,6,16,21}$ Therefore, this study was aimed at assessing the relationship between late diagnosis of HIV and HIVrelated mortality.

\section{Methods}

\section{Study design and setting}

A retrospective cohort study was conducted in general hospitals of Central Zone Tigray, Ethiopia by reviewing patients' records from ART clinics between 2010 and 2015. Tigray regional state, located $1,024 \mathrm{~km}$ to the north of Addis Ababa, the capital city of Ethiopia, and Central Zone are located 240 $\mathrm{km}$ from Mekelle, the capital city of Tigray regional state. The zone has 12 districts called "weredas" and a total of eight hospitals. It has one referral, three general, and four primary hospitals. In this study, record reviews from the three general hospitals are included for analysis.

\section{Sampling and study population}

The source population included all HIV patients, aged $\geq 15$ years, who had received no ART and those who presented for ART follow-up at the three general hospitals from July 2010 to June 2015. Sampled HIV patients who fulfilled the inclusion criteria were included for analysis. The sample size was calculated using stpower Cox in Stata version 12.0 software package (StataCorp LP, College Station, TX, USA). Estimation was based on assumptions with power of $80 \%, \alpha$ (type I) error of $5 \%, 8.85 \%$ proportion of death among exposed (CD4 cell count $<350$ cells $/ \mathrm{mm}^{3}$ ), hazard ratio (HR) of 2.15 with 0.5 standard deviation (SD), and lost to follow-up rate of $5 \%{ }^{22}$ Based on the above assumptions, the total sample size included for analysis had 638 patients with exposed to nonexposed ratio of $1: 1$. Patients were proportionally allocated to each hospital according to the number of enrolled HIV patients during the study period. Thus, 310,218 , and 110 HIV patients were included for analysis from Aksum St Mary, Adwa, and Tembien Abi-Adi General Hospitals, respectively (Tigray Health Bureau, unpublished data, 2014). Patients with an incomplete baseline CD4 cell count were excluded. Then, systematic random sampling method was used to sample individuals from the eligible patients in the records.

\section{Variables and measurement}

The outcome variable is a binary outcome, categorized as censored (alive HIV patients) and time to death event (deceased HIV patients). Censored patients are those who were alive until the most recent follow-up period and deceased patients are those who died at any time during the 5 years' retrospective follow-up period.

The main exposure variable is period of diagnosis of HIV, categorized as early diagnosis versus late diagnosis of HIV. Exposed patients are those with late diagnosis of HIV (who present with CD4 cell count $<350$ cells $/ \mathrm{mm}^{3}$ ), whereas nonexposed patients are those with early diagnosis of HIV (who present with CD4 cell count $\geq 350$ cells $/ \mathrm{mm}^{3}$ ).

\section{Other independent variables (possible covariates)}

Sociodemographic variables such as age, sex, marital status, level of education, religion, occupation, residence, past medical history of any opportunistic infections (OIs), clinical factors such as weight, functional status, WHO clinical staging, and hemoglobin level were included as possible covariates for analysis.

\section{Data collection tool and quality assurance mechanisms}

A data collecting checklist was prepared based on routine data registration protocol using standardized HIV care and followup forms employed by the pre-ART and ART clinics in health facilities of Ethiopia. Data were extracted from records by three ART staff nurses working in the three selected hospitals using the prepared data collecting checklist after receiving 2 days training on how to extract data from the records. Data measured during enrollment of patient or, if not available, data measured within 4 weeks of enrollment were extracted 
as baseline data. To assure quality of data extraction, a pretest was conducted in 5\% (32 patients) of the sampled individuals from Suhul Hospital, Shire, Northwest Tigray, Ethiopia.

\section{Data management and analysis procedures}

Data were double entered into EpiData version 3.1 software (Odense, Denmark) and transferred into Stata version 12 software for analysis. Prior to analysis, data were cleaned for completeness using frequency and cross-tabulation. Recoding, categorization, and sorting of data to facilitate analysis were done using the Stata software. Person-days of follow-up were calculated by subtracting date of HIV-related death or last date of follow-up for censoring from the date of HIV confirmation of patients. Both bivariable and multivariable Cox proportional hazard regression models were used to verify the effect of late HIV diagnosis on HIV-related death of patients and other independent predictors of mortality at $5 \%$ level of significance $(\alpha)$. Only variables which were significant in the bivariable analysis were entered into the final model. The assumptions, multicollinearity, normality, and proportionality of hazards over time were checked. The $P$-value of the proportionality of hazards over time in global test, using Schoenfeld residuals, was 0.49. Even though the $P$-value was significant in the bivariable analysis, baseline WHO clinical staging was not included in the final model because it demonstrated collinearity with the main exposure variable (baseline CD4 cell count). Variables which were significant $(P$-value $<0.05)$ in the multivariate analysis were considered independent predictors of HIV-related mortality.

\section{Ethical consideration}

This study obtained ethical approval from the Institutional Review Board of Aksum University College of Health Sciences. In addition, the medical directors' offices of each hospital granted permission to use the patients' data for this study. All data had no personal identifiers and were kept confidential and therefore did not require informed consent.

\section{Results}

\section{Characteristics of cohorts}

A total of $638 \mathrm{HIV}$ patients from the record reviews were analyzed having a mean age of $34.25( \pm 0.38 \mathrm{SD})$ years, a mean hemoglobin level of $12.51( \pm 0.08 \mathrm{SD}) \mathrm{mg} / \mathrm{dL}$, and a mean weight of $50.66( \pm 0.38 \mathrm{SD}) \mathrm{kg}$. About two-thirds, $439(68.8 \%)$, of the patients were females. Nearly one-third, 194 (30.4\%), had no formal education. About half, 327 $(51.2 \%)$, of the patients were married. Most of the patients were Christian by religion, urban by residence, and unemployed by occupation with a magnitude of 601 (94.2\%), $454(71.2 \%)$, and $460(72.1 \%)$, respectively. Regarding the baseline clinical and laboratory characteristics of patients, about $90 \%$ of them, 572 (89.7\%), had at least one OI, more than one-third, $234(36.7 \%)$, were stage III or stage IV by WHO clinical staging, and the majority, 517 (81.0\%), were working by functional status. Few, 48 (7.5\%), of the patients died due to HIV (Table 1).

\section{Late HIV diagnosis as a predictor of HIV- related mortality}

In all, $638 \mathrm{HIV}$ patients, contributing 2,105.6 person-years of follow-up, were followed for 5 years retrospectively. Of these,

Table I Baseline characteristics and incidence of mortality among HIV-infected patients followed from 2010 to 2015 at general hospitals of Central Zone, Tigray, northern Ethiopia

\begin{tabular}{|c|c|c|}
\hline Variable $(n=638)$ & Category & $\mathbf{N}(\%)$ \\
\hline Age range (years) & $15-39$ & $477(74.8)$ \\
\hline$(\mu=34.25 \pm 0.38 \mathrm{SD})$ & $\geq 40$ & $161(25.2)$ \\
\hline \multirow[t]{2}{*}{ Sex } & Male & $199(31.2)$ \\
\hline & Female & $439(68.8)$ \\
\hline \multirow[t]{3}{*}{ Educational level } & No formal education & $194(30.4)$ \\
\hline & Primary education & $265(41.5)$ \\
\hline & Secondary and above & $179(28.1)$ \\
\hline \multirow[t]{2}{*}{ Religion } & Christian & $601(94.2)$ \\
\hline & Muslim & $37(5.8)$ \\
\hline \multirow[t]{2}{*}{ Residence } & Urban & 454 (7I.2) \\
\hline & Rural & $184(28.8)$ \\
\hline \multirow[t]{3}{*}{ Marital status } & Unmarried & $137(2 \mid .5)$ \\
\hline & Married & $327(51.2)$ \\
\hline & Divorced or widowed & $174(27.3)$ \\
\hline \multirow[t]{2}{*}{ Occupation } & Employed & $178(27.9)$ \\
\hline & Unemployed & $460(72.1)$ \\
\hline \multirow[t]{2}{*}{ Presence of any OI } & No & $66(10.3)$ \\
\hline & Yes & $572(89.7)$ \\
\hline \multirow[t]{2}{*}{ Baseline WHO stage } & | or || & $404(63.3)$ \\
\hline & III or IV & $234(36.7)$ \\
\hline Baseline CD4 cell count & $\geq 350$ & $319(50.0)$ \\
\hline$\left(\right.$ cells $\left./ \mathrm{mm}^{3}\right)$ & $<350$ & $319(50.0)$ \\
\hline \multirow[t]{3}{*}{ Baseline functional status } & Working & $517(81.0)$ \\
\hline & Ambulatory & $84(13.2)$ \\
\hline & Bedridden & $37(5.8)$ \\
\hline Baseline hemoglobin level & $\geq 11 \mathrm{mg} / \mathrm{dL}$ & $513(80.4)$ \\
\hline$(\mu=|2.5| \pm 0.08 \mathrm{SD})$ & $<11 \mathrm{mg} / \mathrm{dL}$ & $125(19.6)$ \\
\hline Baseline weight (kg) & $<40$ & $62(9.7)$ \\
\hline \multirow[t]{2}{*}{$(\mu=50.66 \pm 0.38 \mathrm{SD})$} & $40-60$ & $473(74.1)$ \\
\hline & $>60$ & $103(16.1)$ \\
\hline Incidence of death, & Censored & $590(92.5)$ \\
\hline $\begin{array}{l}48 \text { (7.5\%); } 95 \% \mathrm{Cl} \\
(5.5 \%-9.6 \%)\end{array}$ & Event (died) & $48(7.5)$ \\
\hline
\end{tabular}

Abbreviations: CD4 cells, cluster of differentiation 4 cells; $\mathrm{Cl}$, confidence interval; HIV, human immunodeficiency virus; OI, opportunistic infection; SD, standard deviation; WHO, World Health Organization; $\mu$, mean. 
$48(7.5 \%)$ subjects died throughout the 5 year follow-up period, with an overall HIV-related mortality rate of 2.28 per 100 person-years.

Survival of HIV patients within the 5 years retrospective follow-up using Kaplan-Meier (log rank) test showed that there is a statistically significant difference between lately diagnosed (CD4 count $<350$ cells $/ \mathrm{mm}^{3}$ ) and early diagnosed (CD4 count $\geq 350$ cells $/ \mathrm{mm}^{3}$ ) HIV with chi-square result of 2.77 and $P$-value of 0.04 . Adjusting all other variables in the multivariable Cox proportional hazard regression model, late diagnosis of HIV in patients (CD4 cell count $<350$ cells $/ \mathrm{mm}^{3}$ ) had a higher risk of HIV-related mortality with adjusted hazard ratio $(\mathrm{AHR})=3.22,95 \%$ confidence interval (CI) 1.17-8.82 than early diagnosis of HIV (CD4 cell count $\geq 350$ cells $/ \mathrm{mm}^{3}$ ). Rural residents were more likely to die $(\mathrm{HR}=1.96,95 \% \mathrm{CI}: 1.05-3.68)$ than urban residents. Unemployed patients had a higher risk of mortality (AHR $=2.70,95 \%$ CI: $1.03-7.08)$ than employed patients. Patients who were bedridden and ambulatory at baseline were more likely to exhibit HIV-related mortality than patients with working baseline functional status $(\mathrm{AHR}=2.98,95 \% \mathrm{CI}$ : 1.45-6.13 and AHR $=2.54,95 \%$ CI: $1.05-6.15$, respectively). Patients with a baseline hemoglobin level of $<11 \mathrm{mg} / \mathrm{dL}$ had higher risk of mortality (AHR $=3.06,95 \% \mathrm{CI}$ : $1.51-6.23$ ) than patients with baseline hemoglobin level $\geq 11 \mathrm{mg} / \mathrm{dL}$ (Table 2).

\section{Discussion}

The overall incidence of HIV-related death among patients on ART follow-up in general hospitals of Central Zone of Tigray, Ethiopia over 5 years in this study was 7.5\% (with 95\% CI 5.5\%-9.6\%). Late diagnosis of HIV was a predictor of HIV-related death. Patients with late diagnosis of HIV (CD4 cell count $\leq 350$ cells/mm3) showed three-fold higher rates of death from HIV compared to patients with early diagnosis (CD4 cell count $>350$ cells $/ \mathrm{mm}^{3}$ ). Other studies also supported the finding of the current study that baseline CD4 cell count is a significant laboratory predictor of HIVrelated death, in a sense that patients with higher baseline CD4 cell counts are associated with longer survival. ${ }^{19,23-26}$

Table 2 Cox regression analyses model of baseline predictors for HIV patients followed from 2010 to 2015 at general hospitals of Central Zone, Tigray, northern Ethiopia

\begin{tabular}{|c|c|c|c|c|c|}
\hline \multirow[t]{3}{*}{ Variable $(n=638)$} & \multirow[t]{3}{*}{ Category } & \multicolumn{2}{|c|}{ Patient outcome } & \multirow[t]{3}{*}{ CHR (95\% Cl) } & \multirow[t]{3}{*}{ AHR $(95 \% \mathrm{Cl})$} \\
\hline & & Censored & Died & & \\
\hline & & $\mathbf{N}(\%)$ & $\mathbf{N}(\%)$ & & \\
\hline Baseline CD4 cell count (cells/ & $\geq 350$ & $314(98.4)$ & $5(1.6)$ & I & I \\
\hline $\left.\mathrm{mm}^{3}\right)$ & $<350$ & $276(86.5)$ & $43(13.5)$ & $8.47(3.35-21.38)$ & $3.22(1.17-8.82)$ \\
\hline \multirow[t]{2}{*}{ Sex } & Male & $178(89.5)$ & $21(10.5)$ & $1.92(1.08-3.39)$ & $1.68(0.86-3.31)$ \\
\hline & Female & $412(93.8)$ & $27(6.2)$ & I & $\mathrm{I}$ \\
\hline \multirow[t]{2}{*}{ Residence } & Urban & $433(95.4)$ & $21(4.6)$ & I & I \\
\hline & Rural & $157(85.3)$ & $27(14.7)$ & $3.56(2.0 I-6.3 I)$ & $1.96(1.05-3.68)$ \\
\hline \multirow{3}{*}{ Marital status } & Unmarried & $125(91.2)$ & $12(8.8)$ & I & $\mathrm{NI}$ \\
\hline & Married & 307 (93.9) & $20(6.1)$ & $0.57(0.28-1.18)$ & $\mathrm{NI}$ \\
\hline & Divorced or widowed & $158(90.8)$ & $16(9.2)$ & $0.92(0.43-1.94)$ & $\mathrm{NI}$ \\
\hline \multirow[t]{2}{*}{ Occupation } & Employed & $173(97.2)$ & $5(2.8)$ & 1 & 1 \\
\hline & Unemployed & $417(90.7)$ & $43(9.3)$ & 3.76 (1.49-9.49) & $2.70(1.03-7.08)$ \\
\hline \multirow{2}{*}{ Presence of any OI } & No & $52(78.8)$ & $14(2 \mid .2)$ & I & I \\
\hline & Yes & $538(94.1)$ & $34(5.9)$ & $3.75(2.01-6.98)$ & $0.74(0.37-1.46)$ \\
\hline \multirow{3}{*}{ Baseline functional status } & Working & $500(96.7)$ & $17(3.3)$ & I & 1 \\
\hline & Ambulatory & $66(78.6)$ & $18(21.4)$ & $7.53(3.88-14.63)$ & $2.54(1.05-6.15)$ \\
\hline & Bedridden & 24 (64.9) & $13(35.1)$ & $12.78(6.20-26.33)$ & $2.98(1.45-6.13)$ \\
\hline \multirow[t]{2}{*}{ Baseline hemoglobin level } & $\geq 11 \mathrm{mg} / \mathrm{dL}$ & $497(96.9)$ & $16(3.1)$ & I & I \\
\hline & $<11 \mathrm{mg} / \mathrm{dL}$ & $93(74.4)$ & $32(25.6)$ & $9.95(5.45-18.15)$ & $3.06(1.5 I-6.23)$ \\
\hline \multirow[t]{3}{*}{ Baseline weight (kg) } & $<40$ & $44(70.8)$ & $18(19.2)$ & $5.54(2.20-13.97)$ & $1.95(0.68-5.56)$ \\
\hline & $40-60$ & $449(94.9)$ & $24(5.1)$ & $0.89(0.36-2.17)$ & $0.66(0.26-1.66)$ \\
\hline & $>60$ & $97(94.2)$ & $6(5.8)$ & I & I \\
\hline \multirow[t]{2}{*}{ Baseline WHO stage } & I and II & $396(98.0)$ & $8(2.0)$ & I & $\mathrm{NI}$ \\
\hline & III and IV & $194(82.9)$ & $40(17.1)$ & $9.45(4.43-20.20)$ & $\mathrm{NI}$ \\
\hline
\end{tabular}

Note: Data shown in bold indicates statistical significance $(P<0.05)$.

Abbreviations: AHR, adjusted hazard ratio; CD4 cells, cluster of differentiation 4 cells; CHR, crude hazard ratio; $\mathrm{Cl}$, confidence interval; HIV, human immunodeficiency virus; NI, not included; OI, opportunistic illness; WHO, World Health Organization. 
To effectively treat HIV/AIDS and have positive outcomes for individual patients, HIV should be diagnosed as early as possible, when the individual has a CD4 cell count above 350 cells $/ \mathrm{mm} .{ }^{16,21}$ It is therefore very important to start ART at higher CD4 counts which inversely affects transmission and mortality of HIV/AIDS.

Rural patients with HIV had higher hazard of death compared to urban patients. Being unemployed by occupation was also another significant predictor of HIV-related mortality among patients with HIV. Other studies have also revealed rural residence and unemployment as demographic predictors of survival among patients with HIV. ${ }^{26,27}$

Baseline blood hemoglobin level and baseline functional status of patients were also predictors of survival among patients with HIV in this study. Patients with baseline hemoglobin level $<11 \mathrm{mg} / \mathrm{dL}$ were more likely to die of HIV/AIDS than their counterparts. Patients who were bedridden and ambulatory in baseline functional status were at a higher risk of death from HIV than patients who had working baseline functional status. This is due to the fact that immunecompromised individuals are at higher risk of poor prognosis from any disease than immune-competent individuals. This finding is most likely due to the fact that patients who are bedridden are more likely exposed to different infections and have the possibility to have several OIs which lower immunity and thereby lead to early death. ${ }^{28}$

Patients with low baseline hemoglobin level were at a higher risk of death from HIV than their counterparts. This is because anemic patients, as a result of super-infections to HIV, require more time to recover from their illness or become totally unable for good prognosis of recovery from their illness though they are under ARV drugs. Finally, this poor prognosis of the illness leads to death.

The main limitation of this study is that the data we used are secondary data and cannot incorporate other possible predictors of HIV-related mortality such as drug resistance, substance abuse, unspecified OIs, and other possible confounders.

\section{Conclusion and recommendation}

Late diagnosis of HIV has increased mortality. Rural residence, unemployment, bedridden and ambulatory patients (as compared to those who are working), and baseline hemoglobin level $<11 \mathrm{mg} / \mathrm{dL}$ were also independent predictors of HIV-related mortality. The study showed a significant positive relationship between late HIV diagnosis and mortality; therefore, to control death from HIV/AIDS, governmental policy makers and nongovernmental organizations should have a strong focus on identifying HIV-infected individuals as early as possible. Patients with poor baseline clinical and laboratory conditions should also be given more emphasis as their disease progression is more rapid and leads to earlier death.

\section{Acknowledgments}

We would like to express our gratitude to Aksum University College of Health Sciences, Department of Public Health for giving us this opportunity to do this research. We would also like to acknowledge Aksum St Mary, Adwa, and Abi-Adi general hospitals for their permission to get the required data. Finally, we appreciate the assistance of all the data collectors and supervisors for carefully undertaking their roles.

\section{Author contributions}

HB and MA designed the study; HB, MA, FA and TA were involved in data management and write up of the study. HB, MA, FA, TA and SH analyzed the data and discussed the findings. MA wrote the original draft of the manuscript. All authors contributed toward data analysis, drafting and revising the paper and agree to be accountable for all aspects of the work. All authors were involved and approved the final draft of the manuscript.

\section{Disclosure}

The authors report no conflicts of interest in this work.

\section{References}

1. WHO. Update: Ethiopia HIV/AIDS progress in 2014. 2015. Available from: www.who.int/hiv/pub/progressreports/en. Accessed March 12, 2017.

2. Lima VD, Louren L, Yip B, Hogg RS, Phillips P, Montaner JSG. AIDS incidence and AIDS-related mortality in British Columbia, Canada, between 1981 and 2013: a retrospective study. Lancet HIV. 2015;2(3):92-97.

3. Damtew B, Mengistie B, Alemayehu T. Survival and determinants of mortality in adult HIV/AIDS patients initiating antiretroviral therapy in Somali region, Eastern Ethiopia. Pan Afr Med J. 2015;22:1-8.

4. WHO. Media center, HIV/AIDS Fact sheet [updated July, 2017]. Available from http://www.who.int/mediacentre/factsheets/fs360/en/. Accessed September 7, 2017.

5. 2014 Progress reports submitted by countries [webpage on the Internet]. UNAIDS 2014 progress report. Available from: http://www.unaids.org/ en/dataanalysis/knowyourresponse/countryprogressreports/2014count ries/. Accessed January 21, 2017.

6. UNAIDS. The gap report. 2013. Available from: www.unaids.org/ sites/default/files/media_asset/UNAIDS_Gap_report_en.pdf. Accessed March 10, 2017.

7. Central Statistical Agency and ICF International. Ethiopia demographic and health survey 2011. 2012: 1-452. Available from: https://www. unicef.org/ethiopia/ET_2011_EDHS.pdf. Accessed July 13, 2016.

8. Bassi SS, Bland JM, Martin F. High rates of fatality due to AIDS without universal HIV testing. J AIDS Clin Res. 2014;5(4):291.

9. Ayalew J, Moges H, Worku A. Identifying factors related to the survival of AIDS patients under the follow-up of antiretroviral therapy (ART): the case of South Wollo. Int J Data Envelop Anal Oper Res. 2014;1(2):21-27. 
10. Federal HIV/AIDS Prevention and Control Office. Guidelines for HIV counseling and testing in Ethiopia. 2007. Available from: http:// www.who.int/hiv/topics/vct/ETH_HCT_guidelinesJune26_clean.pdf. Accessed January 8, 2017.

11. D'Arminio Monforte A, Antinori A, Girardi E, et al. HIV-infected late presenter patients. AIDS Res Treat. 2012;2012:12-14.

12. Delpierre C, Dray-Spira R, Cuzin L, et al. Correlates of late HIV diagnosis: implications for testing policy. Int J STD AIDS. 2007;18(5):312-317.

13. Beyene MB, Beyene HB. Predictors of late HIV diagnosis among adult people living with HIV/AIDS who undertake an initial CD4 T cell evaluation, northern Ethiopia: a case-control study. PLoS One. 2015;10(10):1-12.

14. Harris J, Khatri R. Late Diagnosis of HIV in the United Kingdom: An Evidence Review [dissertation]. Liverpool, UK: Liverpool John Moores University; 2015: 1. Available from: http://www.cph.org.uk/wp-content/ uploads/2015/12/Late-HIV-diagnosis-rapid-evidence-review_final_covers.pdf. Accessed April 17, 2017.

15. Antinori A, Coenen T, Costagiola D, et al. Late presentation of HIV infection: a consensus definition. HIV Med. 2011;12(1):61-64.

16. Opde Coul ELM, van Sighem A, Brinkman K, et al. Factors associated with presenting late or with advanced HIV disease in the Netherlands, 1996-2014: results from a national observational cohort. BMJ Open. 2016;6(1):e009688.

17. Celesia BM, Castronuovo D, Pinzone MR, et al. Late presentation of HIV infection: predictors of delayed diagnosis and survival in eastern Sicily. Eur Rev Med Pharmacol Sci. 2013;17(16):2218-2224.

18. Mulissa Z, Jerene D, Lindtjørn B. Patients present earlier and survival has improved, but pre-ART attrition is high in a six-year HIV cohort data from Ethiopia. PLoS One. 2010;5(10):e13268.

19. Hosein SR. Deaths due to late HIV diagnosis still a problem. The Body PRO. 2013: 59-62. Available from: http://www.thebodypro.com/ content/72183/deaths-due-to-late-hiv-diagnosis-still-a-problem.html. Accessed December 19, 2016.
20. CDC fact sheet. Today's HIV/AIDS epidemic. 2016. Available from: https:// www.cdc.gov/nchhstp/newsroom/docs/factsheets/todaysepidemic-508.pdf. Accessed November 5, 2016.

21. Krentz HB, Gill MJ. The direct medical costs of late presentation $(<350 / \mathrm{mm})$ of HIV infection over a 15 -year period. AIDS Res Treat. 2012;2012:757135.

22. Tadesse K, Haile F, Hiruy N. Predictors of mortality among patients enrolled on antiretroviral therapy in Aksum hospital, Northern Ethiopia: a retrospective cohort study. PLoS One. 2014;9(1):e87392.

23. Assefa T, Wencheko E. Survival analysis of patients under chronic HIV-care and antiretroviral treatment at Tikur Anbessa Specialized Hospital, Addis Ababa, Ethiopia. Ethiopian J Health Dev. 2012;26(1): 22-29.

24. Lee SH, Kim K, Lee SG, et al. Causes of death and risk factors for mortality among HIV-infected patients receiving antiretroviral therapy in Korea. J Korean Med Sci. 2013;28(7):990-997.

25. Alvarez-Uria G, Naik PK, Pakam R, Midde M. Factors associated with attrition, mortality, and loss to follow up after antiretroviral therapy initiation: data from an HIV cohort study in India. Glob Health Action. 2013;6:21682.

26. Sieleunou I, Souleymanou M, Schonenberger A, Menten J, Boelaert M. Determinants of survival in AIDS patients on antiretroviral therapy in a rural center in the far-north province, Cameroon. Trop Med Int Health . 2009;14:36-43.

27. Lutalo T, Gray RH, Wawer M, et al. Survival of HIV-infected treatmentnaive individuals with documented dates of seroconversion in Rakai, Uganda. AIDS. 2007;21(6):S15-S19.

28. Addis Alene K, Nega A, Wasie Taye B. Incidence and predictors of tuberculosis among adult people living with human immunodeficiency virus at the University of Gondar Referral Hospital, Northwest Ethiopia. BMC Infect Dis. 2013;13:292.
HIV/AIDS - Research and Palliative Care

\section{Publish your work in this journal}

HIV/AIDS - Research and Palliative Care is an international, peerreviewed open access journal focusing on advances in research in HIV, its clinical progression and management options including antiviral treatment, palliative care and public healthcare policies to control viral spread. The journal is included in PubMed. The manuscript man-

\section{Dovepress}

agement system is completely online and includes a very quick and fair peer-review system, which is all easy to use. Visit http://www.dovepress. com/testimonials.php to read real quotes from published authors. 